\title{
KETERAMPILAN PROSES SAINS SISWA PADA \\ PEMBELAJARAN MATERI SEL DENGAN MODEL PROBLEM BASE LEARNING BERBANTUAN TUTOR SEBAYA
}

\author{
Dinda Tsaniyyah ${ }^{1}$, Aditya Marianti ${ }^{2}$, Wiwi Isnaeni ${ }^{3}$ \\ 1,2,3 Jurusan Pendidikan Biologi Fakultas FMIPA Universitas Negeri Semarang \\ Kampus Sekaran Gunungpati Semarang 50229 Jawa Tengah
}

\begin{abstract}
Abstrak
Penelitian ini bertujuan untuk mengetahui pengaruh pembelajaran dengan model PBL berbantuan tutor sebaya terhadap keterampilan proses sains siswa pada materi sel, dan untuk mengetahui peningkatan KPS siswa. Penelitian ini dilaksanakan di SMAN 1 Salatiga pada semester ganjil tahun ajaran 2018/2019. Rancangan yang digunakan dalam penelitian ini adalah nonequivalen control group design. Populasi dalam penelitian ini adalah seluruh siswa kelas XI MIPA SMAN 1 Salatiga, sedangkan sampel dalam penelitian ini adalah kelas XI MIPA 6 dan XI MIPA 7 yang diambil dengan teknik purposive sampling. Hasil penelitian menunjukkan terdapat perbedaan Mean antara kelas eksperimen dan kelas kontrol yaitu masingmasing 29,44 dan 19,54. Hasil uji t menunjukkan thitung $0,046<0,05$, hal ini menunjukkan bahwa terdapat perbedaan yang signifikan antara kelas kontrol dan kelas eksperimen. Pada kelas eksperimen, rerata peningkatan KPS dasar sebesar $101,57 \%$ dan KPS terintegrasi sebesar 130,32\%. Sedangkan pada kelas kontrol, rerata peningkatan KPS dasar sebesar 60,46\% dan KPS terintegrasi sebesar $89,54 \%$. Berdasarkan hasil penelitian maka dapat disimpulkan bahwa pembelajaran materi sel dengan model PBL berbantuan tutor sebaya berpengaruh positif terhadap KPS siswa, dengan peningkatan KPS meliputi KPS dasar dan KPS terintegrasi.
\end{abstract}

Kata kunci: Problem Base Learning (PBL), Tutor Sebaya, Keterampilan Proses Sains (KPS), Materi Sel.

\section{PENDAHULUAN}

Berdasarkan tuntutan standar kelulusan pada kurikulum 2013, standar kelulusan peserta didik pada tiap tingkat satuan pendidikan didasarkan pada 3 dimensi yaitu sikap, pengetahuan dan keterampilan. Standar kelulusan pada dimensi keterampilan untuk tingkat satuan pendidikan menengah atas mengharuskan peserta didik memiliki keterampilan kreatif, produktif, kritis, mandiri, kolaboratif dan komunikatif yang didapatkan melalui pendekatan ilmiah sebagai pengembangan dari pembelajaran yang berlangsung di kelas (Kemendikbud, 2016). Pembelajaran sains yang lebih menekankan pada proses, mengharuskan siswa untuk membangun pengetahuannya melalui 
serangkaian kegiatan belajar bermakna. Pembelajaran yang menekankan pada proses penting dilakukan agar siswa memahami pengetahuan secara utuh (Sari, 2013). Subali (2009) menyatakan hal ini sesuai dengan hakikat Biologi sebagai sains yang dalam pembelajarannya bertumpu pada proses ilmiah yang membutuhkan keterampilan proses sains (KPS).

Berdasarkan hasil pengamatan langsung, pembelajaran yang dilakukan oleh guru di sekolah sudah cukup beragam, guru pernah menerapkan dengan diskusi, siswa diberi tugas presentasi, namun hasilnya masih belum maksimal. Siswa masih belajar Biologi dengan metode menghafal materi dari buku pelajaran, bukan dari pemahaman konsep yang mereka dapatkan lewat kegiatan ilmiah. Selain itu, pembelajaran masih terbatas pada latihan soal, sehingga KPS dalam diri siswa kurang terlatih. Hasil penelitian Subali (2009) menunjukkan bahwa KPS yang masih sulit dilakukan oleh siswa adalah mencatat/merekam data/informasi, membuat inferensi dan merancang investigasi. Oleh sebab itu, perlu dikembangkan sebuah metode belajar yang cocok dengan kondisi siswa.

Untuk meningkatkan KPS siswa salah satu model pembelajaran yang disarankan dalam kurikulum adalah Problem Base Learning. Menurut Rusnayati dan Prima (2011), mengembangkan KPS dapat dilakukan dengan proses pembelajaran yang berorientasi pada pemecahan masalah. Pembelajaran PBL didasarkan pada penyajian suatu permasalahan nyata, siswa secara berkelompok mendiskusikan solusi dari permasalahan yang diajukan. Problem Base Learning (PBL) merupakan pembelajaran yang dirancang dengan menghadapkan siswa pada permasalahan nyata, sehingga siswa dapat berperan aktif dalam menyusun pengetahuannya sendiri yang digunakan untuk memecahakan masalah tersebut (Asfadi, 2014; Etherington, 2011; Purnamaningrum et al., 2012).

PBL diawali dengan menyajikan masalah yang akan memunculkan aktivitas siswa untuk mengidentifikasi berbagai rumusan masalah yang dilanjutkan dengan penyelidikan ilmiah yang membutuhkan kemampuan menganalisis masalah, memperkirakan jawaban, mencari data dan menyimpulkan jawaban permasalahan (Wardani et al., 2012; Maurer \& Neuhold, 2012). Dua hal penting yang harus menjadi pusat pembelajaran dengan PBL adalah pembelajaran aktif dan berpikir kritis (Khoiriyah et al., 2015). Pada PBL siswa dituntut aktif untuk mendapatkan konsep sendiri melalui pemecahan masalah, siswa mengeskplorasi sendiri konsep yang harus mereka kuasai, siswa bertanya dan berargumentasi melalui diskusi, siswa dapat 
mengasah keterampilan investigasi dan menjalani prosedur kerja ilmiah. Dalam penelitiannya, Carrio et al. (2016) menyatakan bahwa kemampuan menyelesaikan masalah siswa akan lebih baik jika menggunakan PBL dibanding dengan pendekatan konvensional.

PBL memiliki karakteristik khas yaitu, pembelajaran dimulai dengan suatu permasalahan, permasalahan berhubungan dunia nyata siswa, siswa membahas permasalahan, dilakukan dalam kelompok kecil, siswa diminta untuk mendemonstrasikan hasil belajar (Juliawan, 2012). Tahapan dalam model PBL meliputi mengorientasikan siswa kepada masalah, mengordinasi siswa untuk belajar, membimbing siswa dalam melakukan eksplorasi, mengembangkan dan menyajikan hasil temuan serta menganalisis alternatif solusi masalah (Priadi, et al. 2012).

Model pembelajaran PBL memiliki kelemahan yaitu kurang cocok diterapkan pada kelas yang memiliki tingkat keragaman siswa yang tinggi, sehingga akan menyulitkan guru dalam pembagian tugas (Shoimin, 2014). Oleh karena itu, perlu dikembangkan cara belajar yang dapat mengoptimalkan proses pembelajaran dengan model PBL. Alternatif pembelajaran yang cocok adalah dengan melatih siswa untuk belajar dengan tutor sebaya. Tutor sebaya dinilai cocok untuk menutup kekurangan PBL, karena dalam pembelajarannya tutor sebaya memanfaatkan siswa dengan kemampuan menyerap informasi dengan cepat untuk membantu siswa lain yang sulit memahami materi.

Rijdt et.al (2011) mendefinisikan tutor sebaya sebagai pembelajaran kolaboratif dengan pengaturan tertentu dimana siswa akan dikelompokkan pada kelompok kecil dengan salah satu siswa berperan sebagai tutor. Burges et.al (2016) juga mendefinisikan tutor sebaya sebagai suatu kelompok sosial yang bukan merupakan kelompok pengajar profesional namun saling membantu dalam hal belajar dan belajar untuk kelompok itu sendiri. Tutor sebaya pada dasarnya adalah pembelajaran antar teman sebaya atau antar peserta didik yang dilakukan dengan siswa yang membantu siswa lain dalam memahami materi (Ulfah, 2012; Sukmadinata, 2007; Lubis et.al, 2010). Maksud dari bantuan teman sebaya adalah untuk menghilangkan kecanggungan, karena bahasa teman cenderung lebih mudah dipahami, selain itu dengan teman sebaya tidak ada rasa enggan, rendah diri, malu dan siswa dapat lebih leluasa mengungkapkan kesulitan-kesulitannya dalam memahami materi (Putra et.al, 2018). Pelaksanaan tutor sebaya juga dapat melatih 
kesabaran siswa terutama untuk siswa yang berperan sebagai tutor karena dituntut untuk bisa mengajarkan materi kepada teman lainnya.

Pembelajaran dengan tutor sebaya juga lebih meningkatkan hasil belajar siswa dibanding dengan pembelajaran langsung (Miftachudin et al., 2015). Pengajaran tutor sebaya lebih efektif dibanding dengan pengajaran oleh guru. Hal ini disebabkan karena persamaan latar belakang yang dimiliki antara tutor dan anggota kelompok, sehingga dalam tahap ini guru hanya berperan sebagai fasilitator saja (Lie, 2004). Tutor sebaya berperan memberikan dukungan sosial, moral dan emosional. Tutor sebaya juga dapat menjadi kelompok belajar bersama yang nyaman dan aman karena kedekatan yang sudah terjalin sesama teman (Sawali, 2007). Hal terpenting dalam pelaksanaan tutor sebaya adalah bantuan teman kepada teman lainnya yang mengalami kesulitan dalam memahami materi.

Tutor sebaya cocok diterapkan untuk materi sel karena materi sel merupakan materi yang membutuhkan kemampuan abstraksi dari siswa, sehingga dengan pembelajaran tutor sebaya siswa bisa saling berdiskusi dan melakukan praktikum dengan lebih terarah sehingga lebih mudah memahami materi.

Materi sel merupakan materi yang diajarkan di SMA kelas XI semester gasal dengan pokok materi yaitu fungsi sel. Kesulitan siswa dalam memahami materi sel adalah karena siswa tidak melihat bentuk sel secara langsung, sehingga siswa harus membayangkan bentuk sel, sehingga membutuhkan model belajar yang sesuai dengan kebutuhan siswa. Materi sel dinilai cocok dengan pembelajaran PBL dan tutor sebaya karena terdapat banyak permasalahan pada kehidupan nyata, serta mencoba mencari solusi permasalahan dengan bantuan tutor.

Berdasarkan latar belakang tersebut, maka perlu dilakukan penelitian tentang "Keterampilan Proses Sains Siswa pada Pembelajaran Materi Sel dengan Model Problem Base Learning Berbantuan Tutor Sebaya."

\section{METODE PENELITIAN}

Desain penelitian yang digunakan yaitu metode penelitian Quasi Experiment dengan jenis eksperimen Nonequivalent Control Group Design. Penelitian dilakukan di SMA N 1 Salatiga yang beralamat di Jln. Kemiri no.1, Kota Salatiga. Waktu pelaksanaan penelitian adalah pada semester gasal tahun 2018 ketika materi sel sedang dipelajari di 
sekolah. Populasi pada penelitian ini adalah siswa kelas XI MIPA SMA N 1 Salatiga. Sampel yang diambil dalam penelitian ini adalah dari kelas XI MIPA, yaitu sebanyak 2 kelas yang dijadikan kelas kontrol dan kelas eksperimen. Teknik pembambilan sampel dengan purposive random sampling. Kelas yang terpilih sebagai kelas sampel adalah XI MIPA 6 sebagai kelas ekperimen dan XI MIPA 7 sebagai kelas kontrol. Instrumen tes yang digunakan adalah soal multiple choice. Instrumen non tes yang digunakan adalah lembar observasi. Data hasil analisis peningkatan KPS siswa dilakuka dengan uji N-gain dan di uji lanjut dengan uji $t$-test, analisis dilakukan dengan aplikasi Microsoft excel dan aplikasi SPSS. Data peningkatan KPS tiap aspek dan observasi penggunaan KPS oleh siswa dengan analisis deskriptif kuantitatif. Pengujian hasil data ini menggunakan aplikasi Microsoft excel.

\section{HASIL DAN PEMBAHASAN}

Data awal penelitian ini yaitu data hasil pretest pada kedua kelas menunjukkan bahwa kondisi awal pada kedua kelas homogen. Hal ini dibuktikan dari hasil homogenitas dimana $t_{\text {hitung }} 0,595>0,05$. Selanjutnya hasil peningkatan KPS pada siswa disajikan pada Gambar 1.

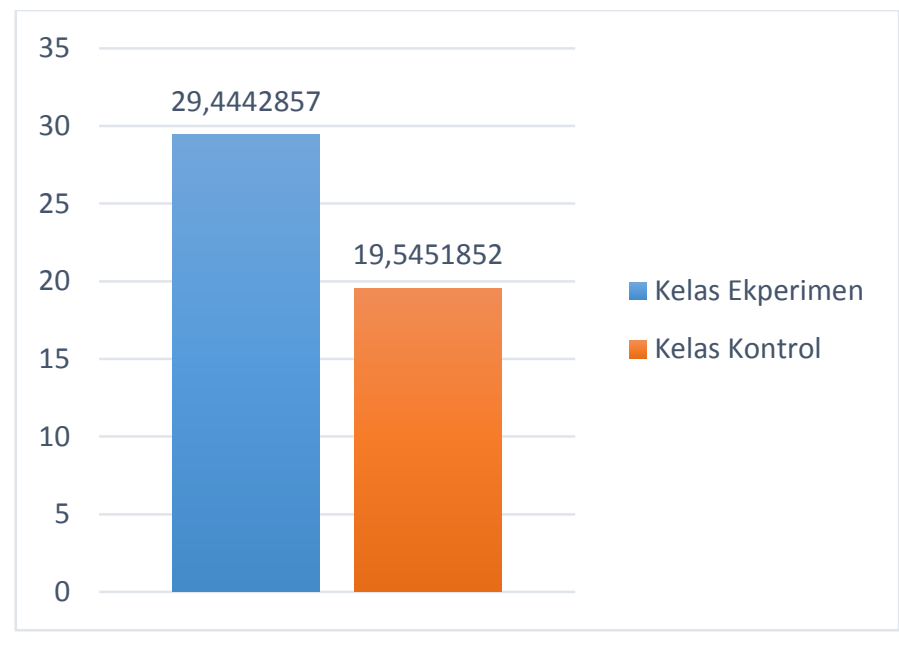

Gambar 1. Hasil Rerata N-gain antara Kelas Eksperimen dengan Kelas Kontrol.

Hasil analisis rerata $\mathrm{N}$-gain tersebut kemudian diuji dengan uji lanjut $t$-test, hasil analisis uji $t$-test menunjukkan bahwa terjadi perbedaan signifikan antara kedua kelas dibuktikan dengan taraf signifikasi sebesar 0.046. Hal ini menunjukkan bahwa ada perbedaan peningkatan KPS antara kelas eksperimen dan kelas control setelah diberikan 
pembelajaran dengan PBL berbantuan tutor sebaya.

Selanjutnya hasil peningkatan KPS tiap aspek tersaji dalam Gambar 2.

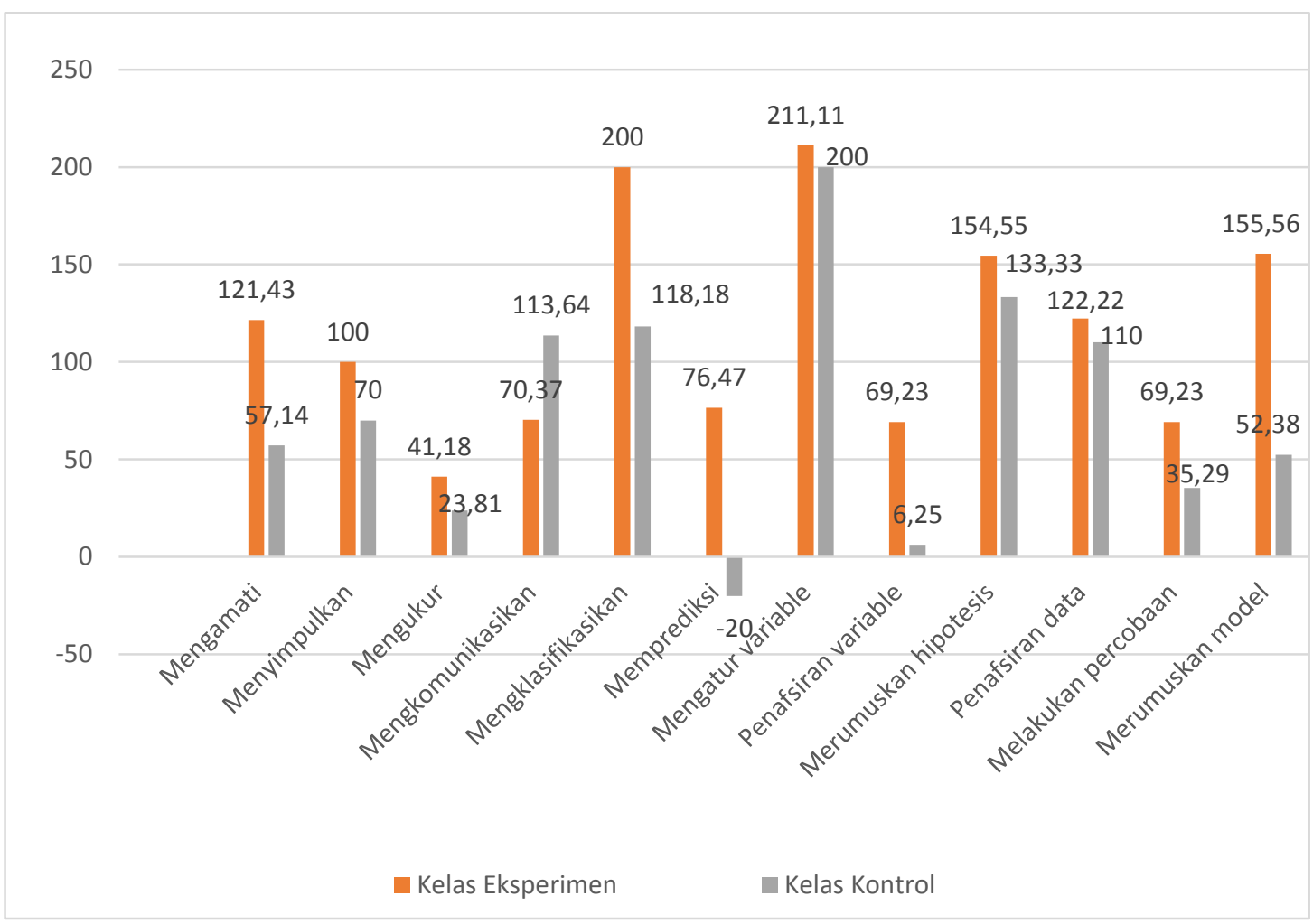

Gambar 2. Hasil Peningkatan KPS tiap aspek.

Berdasarkan isi Gambar 2, dapat diketahui bahwa KPS siswa secara keseluruhan mengalami peningkatan. Pada kelas eksperimen, rerata peningkatan KPS dasar sebesar 101,57\% dan KPS terintegrasi sebesar 130,32\%. Sedangkan pada kelas kontrol, rerata peningkatan KPS dasar sebesar 60,46\% dan KPS terintegrasi sebesar 89,53\%. Selanjutnya hasil observasi penggunaan KPS oleh siswa tersaji dalam Gambar 4. 


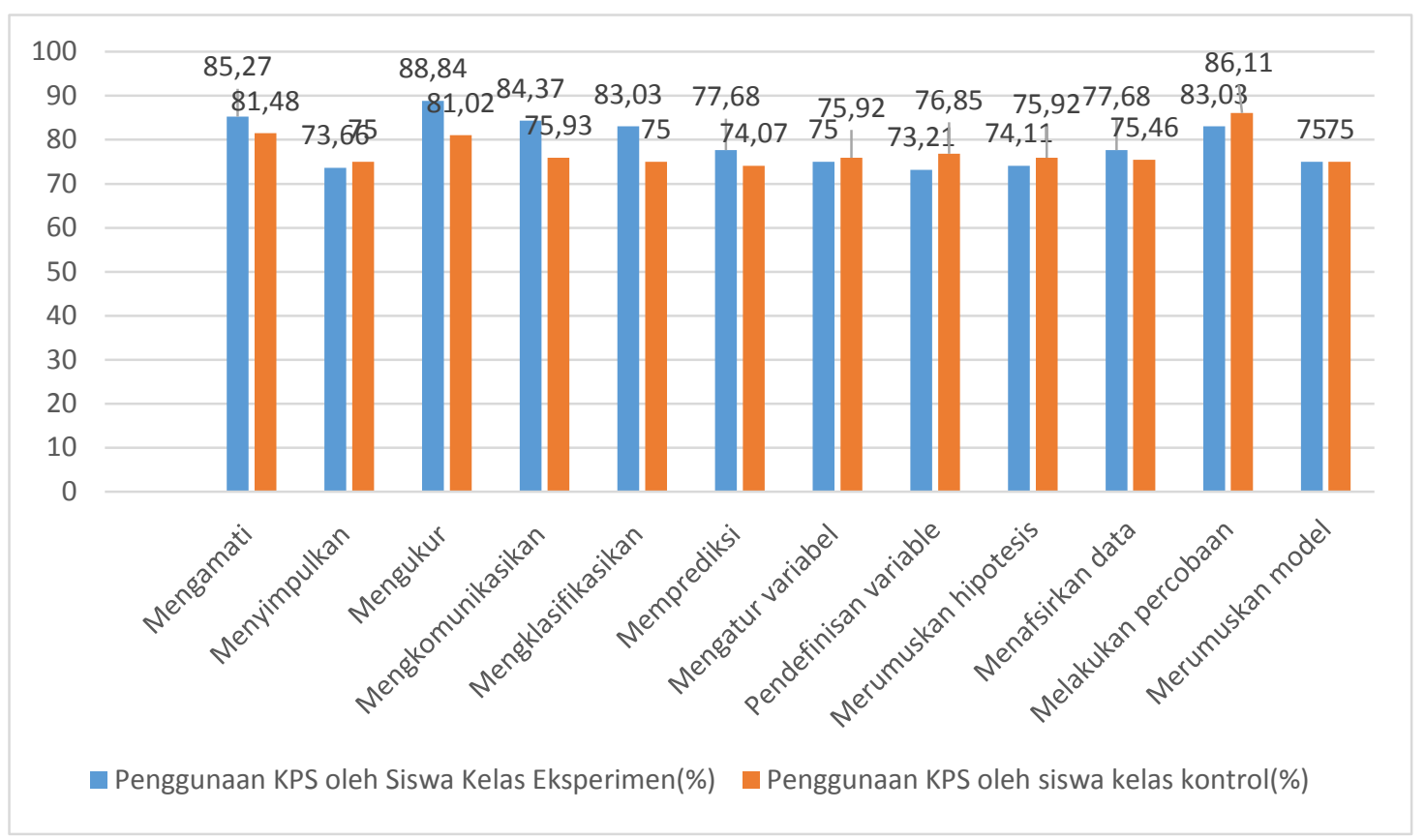

Gambar 3. Hasil observasi penggunaan KPS oleh siswa

Berdasarkan isi Gambar 3, dapat diketahui bahwa penggunaan KPS oleh siswa pada kelas eksperimen maupun kelas kontrol sudah mencapai kategori baik (>70\% $80 \%$ ) dan sangat baik (>85\% - 100\%). Hal ini menunjukkan bahwa siswa aktif dalam kegiatan praktikum.

Berdasarkan hasil analisis peningkatan KPS pada siswa, didapati bahwa terjadi perbedaan N-Gain tiap siswa serta terjadi perbedaan signifikan antara mean N-Gain kelas kontrol dengan mean kelas eksperimen. Hal ini menandakan bahwa pembelajaran dengan PBL berbantuan tutor sebaya berpengaruh positif terhadap KPS siswa pada materi sel. Perbedaan mean $\mathrm{N}$-gain ini terjadi karena ada perbedaan metode mengajar yang digunakan pada kedua kelas. Kelas kontrol dilakukan pembelajaran dengan guru memberikan materi melalui media power point dan ringkasan materi yang dikemas dalam Unit Kegiatan Belajar Mengajar (UKBM), sedangkan pada kelas eksperimen guru memberikan materi dengan model PBL. Pembelajaran dengan model PBL ini juga dipadukan dengan tutor sebaya dimana dalam kelompok kecil siswa, ada satu orang siswa yang berperan sebagai tutor. Pada pembelajaran dengan model PBL berbantuan tutor sebaya, guru merancang pembelajaran di kelas dan kegiatan praktikum untuk bisa melibatkan berbagai KPS yang ada pada diri siswa.

Selama kegiatan pembelajaran berlangsung, siswa dikelompokkan dalam kelompok kecil dimana ada satu siswa yang berperan sebagai tutor yang akan 
membantu teman satu kelompok selama kegiatan belajar mengajar. Tutor yang dipilih didasarkan pada kemampuan akademik dan non akademik yang dimiliki. Tutor yang sudah dipilih kemudian dilatih oleh guru di luar jam pelajaran, hal ini bertujuan mempersiapkan tutor untuk lebih siap dalam pembelajaran di kelas. Kegiatan ini didukung oleh penelitian yang dilakukan oleh Purwanti (2011) yang berpendapat dalam menjalankan tugasnya, tutor terlebih dahulu dilatih oleh guru di luar kelas, sehingga tutor bisa melaksanakan tugasnya dengan lebih baik. Ketika melatih tutor di luar jam pelajaran, guru bukan hanya mempersiapkan tutor dalam segi penguasaan materi saja, selain itu juga menjelaskan tugas tutor di dalam kelas. Guru juga menjelaskan rancangan kegiatan pembelajaran yang akan dilaksanakan, memberikan motivasi kepada tutor untuk lebih percaya diri ketika pembelajaran. Hal ini sejalan dengan penelitian yang dilakukan oleh Blohm (2014) yang berpendapat bahwa melatih tutor secara disiplin efektif untuk mempersiapkan kegiatan belajar di dalam kelas. Pembelajaran dengan PBL berbantuan tutor sebaya yang terjadi dalam kelompokkelompok kecil, memungkinkan terlatihnya berbagai KPS yang terlibat. Hal ini sejalan dengan penelitian yang dilakukan oleh Maurer \& Neuhold (2012) yang berpendapat pembelajaran yang dilakukan dengan PBL dapat merangsang siswa untuk mengidentifikasi masalah dan dilanjutkan dengan kerja ilmiah. Kerja ilmiah yang dilakukan siswa tentu sangat membutuhkan kemampuan KPS. Pembelajaran dengan PBL berbantuan tutor sebaya dapat melatih KPS, karena pembelajaran dimulai dengan sebuah permasalahan yang ditemukan pada kehidupan keseharian siswa, kemudian tutor dan teman satu kelompok secara bersama menganalisis permasalahan yang sudah diberikan, setelah itu siswa melakukan presentasi secara singkat hasil diskusi kelompok.

Tutor yang sudah dipilih berdasarkan kriteria tertentu memiliki peran penting dalam kelompok yaitu membimbing diskusi kelompok, tutorlah yang membimbing teman satu kelompok untuk bisa menampilkan kemampuan KPS yang ada dalam diri tiap anggota kelompok, dengan cara menginisiasi jalannya diskusi dalam kelompok. Kemampuan KPS yang terlibat selama pembelajaran dalam kelas yaitu keterampilan mengamati. Tutor bersama teman satu kelompok mengamati permasalahan yang terjadi di kehidupan sehari-hari dengan melibatkan panca indera. Ketika diskusi kelompok diperlukan KPS untuk menafsirkan data. Saat diskusi berlangsung, diperbolehkan untuk mengakses sumber informasi baik dari media cetak maupun media elektronik. Pada saat 
inilah tutor bersama teman satu kelompok mendapatkan informasi dan mencoba menafsirkan informasi tersebut secara berkelompok. Proses ini melatih siswa untuk bisa menggunakan pemahamannya dalam menganalisis informasi dan mengkomunikasikannya dengan teman satu kelompok, sehingga pada tahap ini siswa sudah melibatkan KPS menafsirkan data dan komunikasi. Pembelajaran dalam kelompok kecil ini memungkinkan terjadinya interaksi sesama siswa dalam bentuk tukar pikiran dan pendapat. Kemampuan analisis siswa terlatih dalam kegiatan kelompok kecil ini. Hal ini didukung dengan penelitian yang dilakukan oleh Shidiq et.al (2012) yang menyatakan bahwa dalam memecahkan suatu masalah siswa harus memiliki berbagai keterampilan komplek dalam dirinya. Dalam proses diskusi ini, tutor berperan memberikan jalan tengah jika terjadi beda pendapat dalam kelompok, tutor juga memiliki peran untuk mencoba memberikan pemahaman pada teman lainnya ketika diskusi maupun ketika pembelajaran berlangsung, sehingga dalam proses ini tutor bukan hanya membantu teman satu kelompok dalam melatih kemampuan KPS yang dimiliki, melainkan juga melatih kemampuan menafsirkan data dan komunikasi pada dirinya sendiri.

Pada akhir diskusi kelompok, tutor bersama teman satu kelompok menyiapkan hasil diskusi untuk bisa dipresentasikan, pada tahap inilah kemampuan menyimpulkan akan dilatih, karena pada tahap ini tutor bersama teman sekelompok harus bisa menarik benang merah dari diskusi yang sudah dilakukan sebelum akhirnya dipresentasikan. Pembelajaran dengan model PBL yang dapat melatih kemampuan menganalisis siswa sejalan dengan apa yang disampaikan oleh Asfadi (2014) bahwa PBL adalah model pembelajaran yang dirancang agar siswa mendapat pengetahuan yang dapat digunakan untuk memecahkan masalah.

Pembelajaran dengan model seperti ini juga membantu siswa lain yang masih belum mengerti tentang materi sel namun tidak memiliki kesempatan untuk bertanya dengan guru sehingga siswa tersebut bisa bertanya dengan tutor dan mendiskusikan materi dalam kelompok kecil. Tutor yang sebelumnya sudah dilatih oleh guru di luar jam pelajaran, ketika pembelajaran lebih menguasai materi dan lebih mudah dalam membantu teman satu kelompok untuk memahami materi sel, sehingga seluruh siswa berperan lebih aktif dalam proses pembelajaran. Selain itu, komunikasi antara tutor dan siswa lain dalam kelompok yang merupakan teman sebaya lebih mudah dipahami 
dibanding dengan komunikasi antara guru dan siswa yang usianya tidak sebaya. Hal ini didukung oleh penelitian yang dilakukan oleh Sawali (2007) yang menyatakan bahwa pembelajaran dengan tutor sebaya memanfaatkan hubungan kedekatan yang terjalin antar teman.

Hal ini juga membantu guru dalam pembelajaran, karena dengan adanya tutor yang sudah dilatih dan menguasai materi, guru terbantu dalam memahamkan siswa tentang materi sel kepada seluruh siswa disebabkan proses pemberian materi dalam pembelajaran bukan hanya dilaksanakan oleh guru di kelas melainkan juga dibantu oleh tutor dalam kelompok kecil. Pembelajaran dengan PBL berbantuan tutor sebaya banyak meningkatkan KPS dasar siswa. Hal ini dapat dilihat dari nilai rerata peningkatan KPS tiap aspek untuk KPS dasar pada kelas eksperimen sebear 101,57\% dan pada kelas kontrol sebesar 60,46\%. Sedangkan KPS terintegrasi pada kelas eksperimen meningkat sebesar 130,32\% dan pada kelas kontrol meningkat sebesar 89,54\%.

Berdasarkan data hasil observasi penggunaan KPS oleh siswa selama kegiatan praktikum dalam kategori baik dan sangat baik, hal ini menandakan bahwa kegiatan praktikum melatih kemampuan KPS siswa. Sebelum kegiatan praktikum, guru memberikan gambaran kegiatan praktikum dan permasalahan yang harus dipecahkan siswa selama kegiatan praktikum, dan siswa diminta untuk memberikan hipotesisnya berupa jawaban sementara berdasarkan analisis masing-masing siswa. Hal ini melatih kemampuan membuat hipotesis dan kemampuan prediksi pada diri siswa. Hipotesis inilah yang coba siswa buktikan kebenarannya melalui kegiatan praktikum.

Pada kegiatan praktikum siswa melakukan kegiatan praktikum dengan mandiri, mencatat dan mengintepretasikan data hasil praktikum, serta membuat laporan kegiatan praktikum. Kegiatan praktikum dapat melatih kemampuan melakukan percobaan dalam diri siswa, karena siswa diminta untuk menyiapkan serta menggunakan alat dan bahan yang dibutuhkan dalam kegiatan praktikum. Selama kegiatan praktikum, siswa melakukan berbagai pengamatan baik pengamatan langsung maupun pengamatan dengan bantuan alat optik seperti mikroskop. Siswa juga diminta mengamati objek secara bergantian sehingga seluruh siswa berkesempatan untuk melatih kemampuan mengamati dalam diri mereka.

Selain kegiatan pengamatan siswa juga melakukan kegiatan pengukuran dengan menggunakan alat bantu ukur seperti penggaris dan neraca ohaus. Ketika melakukan 
kegiatan pengukuran, siswa diminta melakukan pengukuran secara bergantian. Siswa juga diminta mencatat hasil kegiatan praktikum dalam lembar diskusi dan buku catatan yang mereka miliki. Pada akhir kegiatan praktikum guru menguji kemampuan analisis siswa dengan bertanya alasan mengapa didapati hasil seperti yang siswa dapat, hal ini selain bisa mengukur kemampuan analisis juga bisa mengukur kemampuan komunikasi pada diri siswa.

Dalam kegiatan praktikum, tutor memiliki peran yaitu membimbing teman sekelompok untuk bisa melaksanakan kegiatan praktikum dengan baik. Karena pada saat praktikum, guru memberikan kesempatan pada siswa dan tutor untuk bisa melaksanakan kegiatan praktikum secara mandiri, sehingga masing-masing kelompok berusaha untuk menyelesaikan praktikum sebaik mungkin. Karena kegiatan praktikum dilaksanakan mandiri, tutor memiliki kesempatan untuk bisa membantu teman satu kelompok dalam menyelesaikan praktikum. Tutor membimbing teman dalam melaksanakan praktikum baik dari tahap persiapan, pelaksanaan maupun dalam tahap akhir. Pada tahap persiapan, tutor membantu teman satu kelompok dalam menyusun hipotesis kegiatan praktikum, membantu teman satu kelompok dalam mempersiapkan alat dan bahan yang dibutuhkan untuk kegiatan praktikum. Tutor membimbing teman satu kelompok dalam melaksanakan prosedur penelitian, juga merancang kegiatan praktikum yang bisa dilaksanakan bersamaan, karena dalam satu kali praktikum siswa harus menyelesaikan beberapa kegiatan praktikum dalam waktu 2 Jam Pelajaran (2JP), sehingga perlu ada kegiatan praktikum yang dilaksanakan bersamaan supaya seluruh praktikum bisa selesai. Tutor membimbing teman sau kelompok dalam kegiatan pengamatan baik pengamatan langsung maupun pengamatan dengan bantuan alat optik. Pada pengamatan dengan bantuan alat optik, tutor memberikan arahan pada teman satu kelompok ketika ada yang kesulitan dalam menemukan objek dibawah mikroskop. Selain kegiatan pengamatan, tutor juga membantu siswa dalam kegiatan pengukuran dengan menggunakan neraca ohaus, tutor diperbolehkan membantu teman satu kelompok jika ada yang kesulitan dalam menggunakan neraca ohaus.

Setelah seluruh kegiatan praktikum sudah diselesaikan, tutor dan siswa bersamasama mendiskusikan hasil praktikum dan menuliskan hasil tersebut pada buku catatan. Kemudian guru berkeliling pada tiap kelompok untuk melihat hasil kegiatan praktikum tiap kelompok dan menguji kemampuan siswa dalam menafsirkan hasil praktikum. 
Pada akhir tahap penelitian, terjadi peningkatan KPS siswa antara sebelum diberikan pembelajaran dengan model PBL berbantuan tutor sebaya dengan setelah diberikan pembelajaran dengan model PBL berbantuan tutor sebaya. Hal ini dapat dilihat dari hasil analisis data peningkatan KPS tiap aspek. Berdasarkan analisis tersebut, didapati bahwa KPS mengalami peningkatan sampai 211,43\%, hal ini menandakan bahwa pembelajaran yang sudah dilakukan bisa meningkatkan kemampuan KPS siswa. Faktor yang menyebabkan peningkatan ini adalah karena pembentukan kegiatan pembelajaran disesuaikan untuk meningkatkan kemampuan KPS pada diri siswa, sehingga siswa mengalami berbagai proses untuk meningkatkan KPS pada dirinya sendiri. Hasil ini didukung oleh penelitian yang dilakukan oleh Ukoh (2012) yang menyatakan bahwa pembelajaran berbasis masalah memfasilitasi untuk dapat meningkatkan KPS pada diri siswa.

\section{SIMPULAN}

Berdasarkan hasil penelitian, dapat diambil kesimpulan:

1. Keterampilan proses sains siswa pada materi sel dipengaruhi oleh pembelajaran dengan model PBL berbantuan tutor sebaya berdasarkan analisis data peningkatan KPS pada siswa.

2. Jenis keterampilan proses sains siwa yang meningkat meliputi seluruh keterampilan dasar dan keterampilan terintegrasi. 


\section{DAFTAR PUSTAKA}

Asfadi, B. (2014). Pengaruh Model Pembelajaran Berbasis Masalah (Problem Based Learning) Terhadap Hasil Belajar Biologi Siswa Kelas X SMA N 3 Kota Jambi. Skripsi tidak dipublikasikan. Jambi: Universitas Jambi.

Blohm, M., Markus, K., Jan, L., Julia, H., Peter, W., Wolfgang, H., Jana, J., \& Cristoph, N. (2014). Voluntary Undergraduate Technical Skills Training Course to Prepare Students for Clerkship Assignment: Tuttes and Tutors Perspectives. BMC Medical Education, 14(71), 1-11.

Burgess, A., Tim, D., Antonia, J. C., Audrey, M., \& Craig, M. (2016). Peer Tutoring in a Medical School: Perceptions of Tutors and Tutees. BMC Medical Education, 16(85), 1-7.

Carrio, M., Larramona, P., Banos, J. E., \& Perez, J. (2016). Benefits of Using a Hybrid Problem-based Learning Curriculum to Improve Long-term Learning Acquisition in Undergraduate Biology Education. FEMS Microbiology Letters, 363(15), 1-7.

Etherington, M. B. 2011. Investigative Primary Science: A Problem-Based Learning Approach. Australian Journal of Teacher Education, 36(9).

Juliawan, D. 2012. Pengaruh Model Pembelajaran Berbasis Masalah Terhadap Pemahaman Konsep dan Keterampilan Proses Sains Siswa Kelas XI IPA SMA Negeri 2 Kuta Tahun Pelajaran 2011/2012. Skripsi. Denpasar: Universitas Ganesha.

Kementrian Pendidikan dan Kebudayaan. (2016). Permendikbud Tahun 2016 No.20 tentang Standar Kompetensi Lulusan Pendidikan Dasar dan Menengah. Jakarta: Depdiknas.

Khoiriyah, U., Chris, R., Christine, J., \& C. P. M. Van, der Vlauten. (2015). Enhancing Students' Learning in Problem Based Learning: Validation of a Self-assessment Scale for Active Learning and Critical Thinking. BMC Medical Education, 140(15), 1-8.

Lie, A. (2004). Cooperative Learning: Mempraktekkan Cooperative Learning di Ruangruang Kelas. Jakarta: PT. Grasindo.

Lubis, A. R., Binari, M. \& Ari. (2010) Pengaruh Model dan Media Pembelajaran terhadap Hasil Belajar dan Retesi Siswa pada Pembelajaran Biologi di SMP Swasta Muhammadiyah Serbelawan. Jurnal Pendidikan Biologi, 1(3), 186-206.

Maurer, H \& Christine, N. (2012). Problems Everywhere? Strengths and Chalenges of a Problem-Based Learning Approach in European Studies. Paper for the 2012 APSA Teaching and Laerning Conference.

Miftachudin, Budiyono, \& Riyadi. (2015). Efektifitas Model Pembelajaran Two Stay Two Stray dengan Tutor Sebaya dalam Pembelajaran Matematika pada Materi Bnagun Datar Ditinjau dari Kecerdasan Majemuk Peserta Didik Kelas VII SMP 
Negeri di Kebumen Tahun Pelajaran 2013/2014. Jurnal Elektronik Pembelajaran Matematika, 3(3): 233-241.

Purnamaningrum, A., Sri, D., Riezky, M. P., \& Noviawati. (2012). Peningkatan Kemampuan Berpikir Kreatif Melalui Problem Based Learning (PBL) pada Pembelajaran Biologi Siswa Kelas X-10 SMA Negeri 3 Surakarta Tahun Pelajaran 2011/2012. Jurnal Pendidikan Biologi, 4(3), 39-51.

Purwanti, T. (2011). Pembelajaran Sistem Saraf dengan Teknologi Informasi dan Tutur Sebaya di MAN 2 Kudus. Skripsi. Semarang: Universitas Negeri Semarang.

Putra, L. V., Kartika, Y. P., Ika, S. A. K. (2018). Pembelajaran Matematika Model Tutor Sebaya dengan Strategi Heuristik Vee. Journal of Primary and Children's Education, 1(2), 38-44.

Priadi, M. A., Suciati, S., Suparmi. (2012). Pembelajaran Biologi Menggunakan Model Problem Base Learning Melalui Metode Eksperimen Laboratorium dan Lapangan Dtinjau dari Keberbagaman Kemampuan Berpikir Analitis dan Sikap Peduli Lingkungan. Jurnal Inkuiri, 1(3), 217-226.

Rijdt, C. D., Janine, V. D. R., Filip, D., \& Cess, V. D. V. (2012). Rigorously Selected and Well Trained Senior Student Tutors in Problem Based Learning: Student Perception and Study Achievments. Journal Instr Sci, 40(1), 397-411.

Rusnayati, H \& Eka, C. P. (2011). Penerapan Model Pembelajaran Problem Based Learning dengan Pendekatan Inkuiri untuk Meningkatkan Keterampilan Proses Sains dan Penguasaan Konsep Elastisitas pada Siswa SMA. Prosiding Seminar Nasional Penelitian, Pendidikan dan Penerapan MIPA. Yogyakarta: Universitas Negeri Yogyakarta.

Sari, P. M. (2013). Pengaruh Model Pembelajaran Berbasis Praktikum Terhadap Keterampilan Proses Sains, Sikap, Ilmiah, dan Penguasaan Konsep Sistem Regulasi. Skripsi tidak dipublikasikan. Bandung: Universitas Pendidikan Indonesia.

Sawali. (2007). Pengajaran dengan Motode Tutor Sebaya. Jakarta: Rajawali Press

Shoimin, A. (2014). 68 Model Pembelajaran Inovatif dalam Kurikulum 2013. Yogyakarta: Ar-Ruzz Media.

Sidiq, Y., Baskoro, A. P., Puguh, K., \& Bowo, S. (2012). Pengaruh Strategi Pembelajaran INSTAD terhadap Keterampilan Proses Sains. Prosiding Seminar Nasional IX Pendidikan Biologi FKIP UNS. Surakarta: Universitas Sebelas Maret.

Subali, B. (2009). Pengembangan Tes Pengukur Keterampilan Proses Sains Pola Divergen Mata Pelajaran Biologi SMA. Prosiding Seminar Nasional Biologi, Lingkungan dan Pembelajarannya. Yogyakarta: Universitas Negeri Yogyakarta.

Sukmadinata, N. S. (2007). Metode Penelitian Pendidikan. Bandung : Rosdakarya. 
Ulfah, M. (2012). Optimalisasi Hasil Belajar IPA Tentang Sistem Gerak pada Manusia Melalui Metode Diskusi dengan Tehnik Pembelajaran Tutor Sebaya. Jurnal Dinamika, 3(1), 19 - 24.

Wardhani, K., W. Sunarno, dan Suparmi. (2012). Pembelajaran Fisika dengan Model Pembelajaran Problem Based Learning Menggunakan Multimedia dan Model ditinjau dari Kemampuan Berfikir Abstrak dan Kemampuan Verbal Siswa. Jurnal Inkuiri, 1(2): 32-35. 